\title{
Enhancement of the Methodology for Measuring Transport Services Efficiency Indicators in Uzbekistan
}

\author{
Mirzaev Kulmamat, Nasimov Ikrom, Rahimov Zafar
}

\begin{abstract}
Transport as a key factor Transport as a key factor that directly influences the rapid development of any social system is in turn directly linked to the quantitative and qualitative changes of other types of productive forces. The transport service is not only important in the solution of economic tasks, it also helps to develop the road network, bring the village closer to the city, facilitate the permanent work of local personnel and rational use of labor resources. It is worth noting that transport services are also crucial in areas such as enhancing state defense capabilities, strengthening its combat capacity and prompt delivery of relevant content to its intended destination.

The research paper is a contribution to the science-based system of economic indicators that create the conditions for increasing the efficiency of transport services and that will be useful for controlling the targeted use of available resources. There are given recommendations on increasing the number of consumers of transport infrastructure, establishing privileges or preferential tariffs for socially vulnerable segments of the population and identifying sources for covering these costs. Furthermore, the results of the study create the basis for the formation of specific theoretical and methodological foundations aimed at the development of transport services in the Republic of Uzbekistan.
\end{abstract}

Keywords: digital economy, freight transportation, transport services economic indicators.

\section{INTRODUCTION}

Nowadays the intensive growth of the global economy requires further improvement of the transport sector and the entire transport service system. The transport sector is an important component and driving force for the development of the economy of each country. 'Currently, this sector

accounts for $8 \%$ of world's labor, $15 \%$ of overall business costs and $6 \%$ of the world's gross domestic product. ${ }^{1}$

Revised Manuscript Received on March 05, 2020.

* Correspondence Author

Prof. Mirzaev Kulmamat*, Vice-Rector of Samarkand Institute of Economics and Service, Samarkand, Uzbekistan. info@sies.uz, (+998)662213233

Ph.D. Nasimov Ikrom, Head of the Department of Economic Theory in Samarkand Institute of Economics and Service, Uzbekistan, (+99890)5021303

Rahimov Zafar, Teaching assistant of Department of Industrial Economics in Samarkand Institute of Economics and Service, Uzbekistan, (+99890)6578948

(c) The Authors. Published by Blue Eyes Intelligence Engineering and Sciences Publication (BEIESP). This is an open access article under the CC BY-NC-ND license (http://creativecommons.org/licenses/by-nc-nd/4.0/)
As a result of the reforms modernizing and diversifying the economy and innovation development of Uzbekistan over the years of independence, the field of transport services has risen to a new level. Ongoing development of transport and logistics infrastructure and the use of innovation in transport area are the key drivers for enhancing the organizational and economic mechanisms justifying market conditions and forming a regional cluster of transport services.

The correct determination of the quality and effectiveness of various services provided by vehicles requires a scientific and theoretical justification of terms related to the activities of this sector. In this process, an in-depth understanding of the principles reflecting the scientific and theoretical aspects of the transport industry is extremely important. One of the most important is the constant availability and regularity of passenger and freight transport by vehicles. Indeed, timely and regular delivery of all necessary resources to consumers is a prerequisite for the development of the economy and society. Therefore, if there are no modern vehicles and roads, it will be difficult to use natural resources effectively.

The problems of development of transport services and their productivity have been studied by Burmenko T.D.[2], Vahrushina M.A.[11], Bichkov V.P.[1], Dubrovskiy D.A.[3], Ribalkin B.E.[9], Nemolyayeva M.E [8], Savitskaya G.E. [10].

This problem also concerns pressing reforms in our country and its regions, including tourism, as well as the role and importance of transport services in finding their targeted solutions. In this regard, "... travel services can be described as a set of services designed for the fastest possible trips and in convenient conditions for the delivery of tourists and their luggage from one place to another." 2

Transport is important not only for solving economic problems, but it also contributes to the development of the road transport network, brings the village and the city closer together, ensuring the constant work of local personnel and the rational use of human resources. It should be noted that transport services are especially important in areas such as improving the defense capability of the state, strengthening their combat positions and expediting the delivery of troops to their destination.

https://www.itf-oecd.org/search/statistics-and-data?f\%5B0\%5D=field_publ ication_type:648\&f5B1\%5D=field_theme_tax:6

${ }^{2}$ Hamidov O.H. Educational methodological guide on the subject "Organization of transport services" Toshkent -TSEU-2006, p4.

(ished By: Blue Eyes Intelligence Engineering \& Sciences Publication (C) Copyright: All rights reserved.

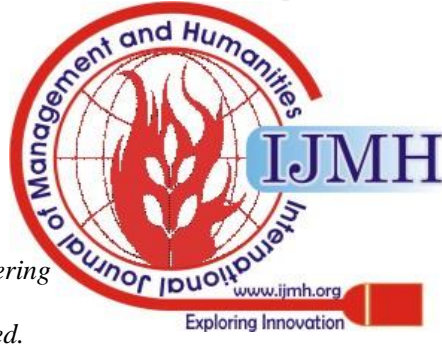


In general, the transport service has specific principles and features for strengthening the material and technical base of various sectors as one of the most important areas of universal service, in our opinion, according to the following definition. That is, transport services are a range of services related to transport services, such as transportation and delivery of passengers to their destination, loading, transportation, unloading, and placement of goods using vehicles in the interests of all types of entities.

The objects of this study were selected enterprises and organizations of transport services of the Republic of Uzbekistan. In the research process, methods of analysis and synthesis, induction and deduction, system analysis, factor analysis, economic-mathematical and statistical analysis were used.

To form a scientifically based system of economic indicators, it is necessary, first of all, to improve the existing organizational and economic mechanisms of transport services. This, in turn, requires the improvement of the elements of the existing organizational and economic mechanisms for the provision of transport services in the republic and its regions, to modify its structural basis and, most importantly, to strengthen its effectiveness and efficiency. In this regard, the author has developed an improved structure of organizational and economic mechanisms for the provision of transport services by economic, regulatory and organizational elements (fig. 1).

World experience shows that the development and implementation of innovative measures for improving the efficiency of transport services is of priority in the following areas: transportation (passenger, cargo) reduce; further increase and full satisfaction of the demand for trans-port services based on reduced travel costs, the efficient use of funds related to the renewal of trans-port parks and the creation of favorable conditions for network workers; expansion of domestic capacity with regard to benefits and decisions (increase of fare, cancellation of privileges, etc.). The analysis shows that at present, the methods of public transport differ greatly from those in many developed countries, especially in the cities. ${ }^{3}$ Qualitative performance of work and how competition or other mechanisms are used, taking into account the types and forms of ownership(Tab. I).

Table-I: Realization of regulation methods of urban passenger transport in foreign countries. ${ }^{4}$

\begin{tabular}{|l|l|l|}
\hline Policy direction & \multicolumn{1}{|c|}{ Actions } & Countries \\
\hline $\begin{array}{l}\text { Performance of } \\
\text { public transport } \\
\text { services }\end{array}$ & $\begin{array}{l}\text { Organization of the process } \\
\text { of providing transport } \\
\text { services based on the state } \\
\text { property }\end{array}$ & $\begin{array}{l}\text { Most of } \\
\text { Europe } \\
\text { countries, } \\
\text { USA, Russia, } \\
\text { Uzbekistan }\end{array}$ \\
\hline Tariff setting & The fare is set by the carrier & $\begin{array}{l}\text { United } \\
\text { Kingdom } \\
\text { (except } \\
\text { London) }\end{array}$ \\
\cline { 2 - 3 } & $\begin{array}{l}\text { The tariff is set by the } \\
\text { customer }\end{array}$ & $\begin{array}{l}\text { Stockholm, } \\
\text { Copenhagen, } \\
\text { London }\end{array}$ \\
\hline
\end{tabular}

${ }^{3}$ Persianov V.A. and others. "Passenger transport economics" Textbook. -M: Knorus, 2012-400 pages

${ }^{4}$ Yerihov M.M. "The Russian practice of managing and financing urban passenger transport in the light of foreign experience." Habarovsk: DVGUPS, 2011, pp.22-27

Retrieval Number: G0711034720/2020@BEIESP

DOI: 10.35940/ijmh.G0711.034720

Journal Website: www.ijmh.org

\begin{tabular}{|c|c|c|}
\hline \multirow{5}{*}{$\begin{array}{l}\text { Relying on the } \\
\text { specifics of } \\
\text { taxation }\end{array}$} & $\begin{array}{l}\text { Introduce city taxes specific } \\
\text { to the needs of urban } \\
\text { passenger transport }\end{array}$ & France \\
\hline & $\begin{array}{l}\text { Payment of taxes to the } \\
\text { local budget from transport } \\
\text { enterprises for lighting } \\
\text { sidewalks and parking lots }\end{array}$ & Greece \\
\hline & $\begin{array}{l}\text { Preferential taxation of } \\
\text { public transport }\end{array}$ & USA \\
\hline & $\begin{array}{l}\text { Taxation of commercial } \\
\text { organizations, offices, } \\
\text { buildings and structures } \\
\text { within } 800 \text { meters from the } \\
\text { subway station building }\end{array}$ & $\begin{array}{l}\text { USA (Los } \\
\text { Angeles), } \\
\text { Canada, Italy, } \\
\text { Spain }\end{array}$ \\
\hline & $\begin{array}{l}\text { Direct financing of urban } \\
\text { passenger transport by } \\
\text { commercial units for stops } \\
\text { near them }\end{array}$ & $\begin{array}{l}\text { Japan, Canada, } \\
\text { Australia, } \\
\text { USA, } \\
\text { Germany and } \\
\text { others }\end{array}$ \\
\hline \multirow[t]{4}{*}{$\begin{array}{l}\text { Features of } \\
\text { budget financing }\end{array}$} & $\begin{array}{l}\text { Annual budget approval of } \\
\text { the Department of } \\
\text { Transportation }\end{array}$ & $\begin{array}{l}\text { USA, Russia, } \\
\text { Uzbekistan }\end{array}$ \\
\hline & $\begin{array}{l}\text { Procurement of mobile } \\
\text { components at the expense } \\
\text { of federal funds }\end{array}$ & USA \\
\hline & $\begin{array}{l}\text { Assistance by the state in } \\
\text { the investment of urban } \\
\text { passenger transport }\end{array}$ & Europe \\
\hline & $\begin{array}{l}\text { Budget subsidies for urban } \\
\text { passenger transport }\end{array}$ & $\begin{array}{l}\text { Luxembourg, } \\
\text { Rome, Berlin, } \\
\text { Vienna, Berlin, } \\
\text { Helsinki, } \\
\text { Stockholm, } \\
\text { Lion, Athens, } \\
\text { Paris, Madrid, } \\
\text { Lisbon, } \\
\text { Copenhagen, } \\
\text { Bern }\end{array}$ \\
\hline \multirow{3}{*}{$\begin{array}{l}\text { The rationale for a } \\
\text { flexible tariff } \\
\text { policy }\end{array}$} & $\begin{array}{l}\text { Tickets for hours, days, } \\
\text { trips, group }\end{array}$ & $\begin{array}{l}\text { Europe, USA, } \\
\text { Uzbekistan }\end{array}$ \\
\hline & Transfer system & USA \\
\hline & $\begin{array}{l}\text { Pay a large fine for a ticket } \\
\text { without a ticket }\end{array}$ & USA, Europe \\
\hline
\end{tabular}

Despite the fact that there are various forms of urban transport services for transport services, the reforms in the field of transport of foreign countries have been made using three models. They differ, among other things, between the market and administrative mechanisms in the area of regulation and transport services, namely:

- Administrative model of management (USA, Canada, Paris);

- Limited competition model (London, capitals of several Scandinavian countries);

- unbiased model of government control (Santiago-Chile, UK, except London).

In France, including Paris, the provision of transport services is carried out by a local authority, and there is virtually no competition between transport services in this area and within. This is due to the fact that transportation services are paid from two sources: travel and budget subsidies.

Published By:

Blue Eyes Intelligence Engineering \& Sciences Publication

(C) Copyright: All rights reserved.

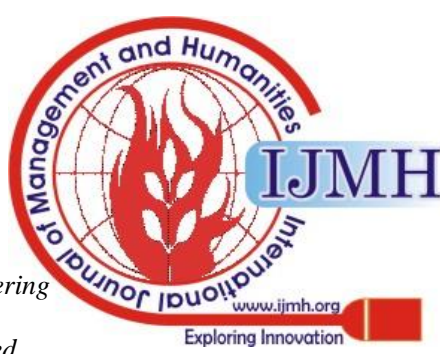




\begin{tabular}{|c|c|c|}
\hline $\begin{array}{l}\text { Formation of an } \\
\text { optimal } \\
\text { territorial and } \\
\text { organizational } \\
\text { structure }\end{array}$ & $\begin{array}{l}\text { Formation of } \\
\text { regulatory } \\
\text { documents of the } \\
\text { relevant service } \\
\text { sector }\end{array}$ & $\begin{array}{l}\text { The use of economic } \\
\text { levers based on a digital } \\
\text { economy (cryptocurrency, } \\
\text { smart contract, date } \\
\text { mining, etc.) }\end{array}$ \\
\hline $\begin{array}{l}\text { Organization of } \\
\text { the optimal } \\
\text { organizational } \\
\text { and financial } \\
\text { structure }\end{array}$ & $\begin{array}{l}\text { Legal safeguards } \\
\text { to ensure } \\
\text { transparency in } \\
\text { related services }\end{array}$ & $\begin{array}{c}\text { Use of foreign investment } \\
\text { and preferential } \\
\text { international lending } \\
\text { systems }\end{array}$ \\
\hline $\begin{array}{c}\text { Use of modern } \\
\text { organizational } \\
\text { standards and } \\
\text { regulations }\end{array}$ & $\begin{array}{c}\text { Creation of an } \\
\text { operational } \\
\text { information and } \\
\text { consulting base } \\
\text { for the relevant } \\
\text { sphere }\end{array}$ & $\begin{array}{c}\text { Introduction of } \\
\text { preferential taxation and } \\
\text { insurance in the relevant } \\
\text { field }\end{array}$ \\
\hline $\begin{array}{l}\text { Service price } \\
\text { differentiation }\end{array}$ & $\begin{array}{l}\text { Formation of a } \\
\text { modern legal } \\
\text { culture of an } \\
\text { appropriate } \\
\text { service sector }\end{array}$ & $\begin{array}{l}\text { Formation of legal and } \\
\text { economic relations in the } \\
\text { relevant field }\end{array}$ \\
\hline \multicolumn{3}{|c|}{$\begin{array}{c}\text { Formation of } \\
\text { organizational } \\
\text { relations based } \\
\text { on international } \\
\text { experience }\end{array}$} \\
\hline
\end{tabular}

Fig.1 Organizational and economic mechanisms for the development of transport services ${ }^{5}$

Improving the organizational and economic mechanisms of transport services will increase the efficiency of provision of transport services and create organizational, regulatory and economic conditions for the accelerated economic development of this industry in the future. Scientifically based economic indicators require first of all determining the features of transport services. Important features of transport services are classified in the following directions and are shown in Fig. 2.

Features of transport services in the Republic of Uzbekistan

Introduction of cheap and high-quality freight and passenger transport services

The need for the formation of various diversification areas

Transport services are one of the service sectors that intensively repays the funds invested in it.

The focus of continuous improvement of quality and technical modernization of the process of transport services

The subjects of transport services belong to different forms of ownership (organization, association, company) and are competitive among themselves

Fig.2 Important features of transport services in the Republic of Uzbekistan ${ }^{6}$

${ }^{5}$ Developed by the author

${ }^{6}$ Based on observations of the author

$T E$ - level of transport service efficiency, in ratios;

$\mathrm{PT}$ - profit received from transport services in soums;

$T C$ - transportation costs, in soums.

If the efficiency ratio is more than 0.1 , then transport services are efficient; if the efficiency ratio is less than 0.1 , services are considered ineffective. The economic efficiency of transport services usually characterizes the effectiveness of the total costs of transport services.

One way to extrapolate dynamic arrays is by flattening them using analytical formulas. Each level of the dynamic array presented here is considered to be the sum of $y_{t}=f(t)+\varepsilon_{t}$ two extremes, where $f(t)$ is the content of the trend, and $\varepsilon_{t}-$ $M \varepsilon=0, D \varepsilon=\sigma^{2}$ is the random number. The purpose of flattening the dynamic series is to find out the "theoretical" levels of $\hat{y}_{t}=f(t)$ based on the formula determined by the empirical data. The most convenient analytical formulas illustrating development trends are presented below (tab. 1).

An analysis of the significance of the identified model is done by checking the "zero-sum hypothesis". The null hypothesis testing is performed using a dispersion analysis and the "zero hypothesis" is expressed as $\mathrm{H}_{0}$ : $\mathrm{D}_{\text {fact }}=\mathrm{D}_{\text {residual }}$ alternative hypothesis $\mathrm{H}_{1}: \quad \mathrm{D}_{\text {fact }}>\mathrm{D}_{\text {residual. }}$ The F-Fisher criterion is used to test these hypotheses.

The actual value of the criterion is determined by the following formula:

$$
F=\frac{\sum_{i=1}^{n}\left(y_{i}-\bar{y}\right)^{2} / k}{\sum_{i=1}^{n}\left(y_{i}-y_{i}\right)^{2} /(n-k-1)}=\frac{\frac{R^{2}}{1-R^{2}} *(n-k-1)}{k},
$$

where:

- $\sum_{i=1}^{n}\left(y_{i}-\bar{y}\right)^{2} / k$ - factor dispersion per one degree of freedom $(\gamma 1=k$ number of degrees of freedom);

- $\sum_{i=1}^{n}\left(y_{i}-y_{i}\right)^{2} /(n-k-1)$ - residual dispersion corresponding to one degree of freedom $(\gamma 2=n-k-1$ number of degrees of freedom); 
- $n$ - the number of observations;

- $k$ - the number of factors (parameters) in the multivariate regression equation.

The actual value of the $\mathrm{F}$ - Fisher criterion $\left(\mathrm{F}_{\text {real }}\right)$ is compared to the critical value $\left(F_{\text {table }}(\alpha ; k ; n-k-1)\right)$. If $F_{\text {real }}>$ $\mathrm{F}_{\text {table, }}$ then the defined model is significant. In the model developed by the analysis of the given dynamic series, the model is defined when the true value of the F-Fisher criterion is greater than the number of degrees of freedom with a table value of $\gamma 1=1$ and a maximum of $\gamma 2=8$ on the threshold (significance level is $\mathrm{p}=0.95$ ), that is, $\mathrm{F}=5.32$. important.

Using the capabilities of the SPSS 19 software package and the method of extrapolation of time series, we developed analytical equations for predicting key indicators of the development of the service sector. (Tab. II and Tab. III).

Table-II: Economic and statistical forecasting equations of the value of passenger turnover in transport

\begin{tabular}{|l|l|l|r|}
\hline № & Equations & R- square & Fisher coefficient \\
\hline 1 & $y=52,647+5,930 \mathrm{t}$ & 0,997 & $2,293,980$ \\
\hline 2 & $y=49,437+23,717 \ln (\mathrm{t})$ & 0,934 & 114,105 \\
\hline 3 & $y=101,189-54,385 / \mathrm{t}$ & 0,703 & 18,937 \\
\hline 4 & $y=\mathbf{4 9 , 9 5 5 + 7 , 2 7 6 t + 0 , 1 2 2 t ^ { 2 }}$ & $\mathbf{0 , 9 9 9}$ & $\mathbf{4 , 6 0 1 , 2 8 8}$ \\
\hline 5 & $\begin{array}{l}y=49,077+8,055 \mathrm{t} \\
-0,291 \mathrm{t}^{2}+0,010 \mathrm{t}^{3}\end{array}$ & 0,999 & $3,080,240$ \\
\hline 6 & $y=53,302^{\mathrm{x}} 0,297^{\mathrm{t}}$ & 0,977 & 343,261 \\
\hline 7 & $y=40,697^{\mathrm{t}} \mathrm{t}^{0,412}$ & 0,973 & 287,177 \\
\hline 8 & $y=\mathrm{e}^{(4,630-0,703 / \mathrm{t})}$ & 0,780 & 28,443 \\
\hline 9 & $y=\mathrm{e}^{(4,028+0,072 \mathrm{t})}$ & 0,977 & 343,261 \\
\hline 10 & $y=56,160^{\mathrm{x}} \mathrm{e}^{0,072 \mathrm{t}}$ & 0,977 & 343,261 \\
\hline
\end{tabular}

The Fisher criterion for predicting the value of passenger turnover in transportation is $F_{\text {real }}=4601,288(4601,288>$ 4.96), with the fourth equation $y=49,955+7,276 t+0,122 t^{2}$, which is the largest of all functions $F_{\text {real }}>4,96$. were considered significant for predictions (Tab. III).

Table-III. Economic and statistical forecasting equations of the total number of passengers transported

\begin{tabular}{|l|l|l|l|}
\hline & Equations & R-square & $\begin{array}{l}\text { Fisher } \\
\text { Coefficient }\end{array}$ \\
\hline 1 & $\boldsymbol{y}=4554,500+344,527 \mathrm{t}$ & 0,986 & 575,497 \\
\hline 2 & $y=4327,733+1404,667 \ln (\mathrm{t})$ & 0,961 & 197,190 \\
\hline 3 & $y=7415,209-3297,437 / \mathrm{t}$ & 0,758 & 25,015 \\
\hline 4 & $\boldsymbol{y}=\mathbf{4 2 4 4 , 1 2 5 + 4 9 9 , 7 1 5 t} \mathbf{- 1 4 , 1 0 8 \mathbf { t } ^ { 2 }}$ & $\mathbf{0 , 9 9 9}$ & $\mathbf{1 6 2 7 , 2 9 9}$ \\
\hline 5 & $\begin{array}{l}y=4032,167+687,710 \mathrm{t} \\
-54,869 \mathrm{t}^{2}+2,470 \mathrm{t}^{3}\end{array}$ & 0,997 & 1116,120 \\
\hline 6 & $y=4703,164^{\times} 1,057^{\mathrm{t}}$ & 0,963 & 206,312 \\
\hline 7 & $y=4497,353^{x} \mathrm{t}^{0,230}$ & 0,985 & 540,161 \\
\hline 8 & $y=\mathrm{e}^{(8,922-0,555 / \mathrm{t})}$ & 0,819 & 36,220 \\
\hline 9 & $y=\mathrm{e}^{(8,456+0,055 \mathrm{t})}$ & 0,963 & 206,312 \\
\hline 10 & $y=4703,164^{\times} \mathrm{e}^{0,055 \mathrm{t}}$ & 0,963 & 206,312 \\
\hline
\end{tabular}

The Fisher criterion for predicting service size and forecasting from this table is $F_{\text {real }}=1627,299$ (1627,299> 4.96), the largest of all equations with $F>4.96$, and the fourth equation $y=4244,125+499,715 t-14,108 t^{2}$ were considered significant for compatibility. As a result, the forecast indicators of the domestic and transport services market development in 2019-2022 years and the most convenient equations for their calculation are given in Table IV.

\section{RESULTS}

As a result, we presented the most significant forecast indicators of the development of the transport services market in the republic in 2019-2021, and also determined their functional relationship (table 4).

Table-IV. Forecast indicators of the development of the transport services sector in the Republic of Uzbekistan for 2019-2021 years

\begin{tabular}{|c|c|c|c|}
\hline № & 1 & 2 & 3 \\
\hline $\begin{array}{l}\text { Name of } \\
\text { indicators }\end{array}$ & $\begin{array}{l}\text { Passenger } \\
\text { turnover in } \\
\text { transport (billion } \\
\text { passenger-km) }\end{array}$ & $\begin{array}{l}\text { Total } \\
\text { number of } \\
\text { passengers } \\
\text { carried } \\
\text { (million } \\
\text { people) } \\
\end{array}$ & $\begin{array}{l}\text { The total volume } \\
\text { of transport } \\
\text { services, billion } \\
\text { soums }\end{array}$ \\
\hline $\begin{array}{l}\text { The most } \\
\text { suitable } \\
\text { features } \\
\text { for } \\
\text { forecasting }\end{array}$ & $\begin{array}{c}y=49,955+7,276 t \\
+0,122 \mathrm{t}^{2}\end{array}$ & $\begin{array}{l}y=4244,125+ \\
499,715 t \\
-14,108 t^{2}\end{array}$ & $\begin{array}{r}y=1715,3+2893,8 t \\
-267,7 t^{2}+25,18 t^{3} \\
\end{array}$ \\
\hline$F_{\text {real }}$ & 4601,3 & 1627,3 & 166,1 \\
\hline \multicolumn{4}{|l|}{ Years } \\
\hline 2018 & 154,8 & 8209,2 & 41403,1 \\
\hline 2019 & 165,2 & 8356,2 & 47966,3 \\
\hline 2020 & 175,7 & 8475,0 & 57163,1 \\
\hline 2021 & 186,5 & 8565,6 & 68157 \\
\hline
\end{tabular}

Source: Information of the State Statistics Committee of the Republic of Uzbekistan, calculated for 2007-2017.

As can be seen from the table, by 2021 the passenger flow is estimated at 186.5 billion passenger per $\mathrm{km}$, the total number of passenger fat transported by this mode of transport will amount to 8565.6 million people and the total volume of transport services will amount to 68157 billion soums, these indicators will increase compared to the 2017 base year, respectively by $43.5 \%, 50.8 \%$ and $88.2 \%$. This trend, in turn, lies in the need to develop transport networks as a whole country and regions, to create enterprises and organizations to provide new types of transport servants, on the basis of modernization and diversification of the transport system, provide foreign investors with cheap and high-quality transport services in international directions, strengthen the role of our country in the world community and effectively implement a strategically significant "road map" in order to improve people's living conditions.

In our opinion, the organizational mechanisms for the development of transport services also include the provision of information on the territorial structure of transport services management, provision of resources, standardization and licensing, regulation of transport services, as well as the provision of information and consulting services related to transport services.

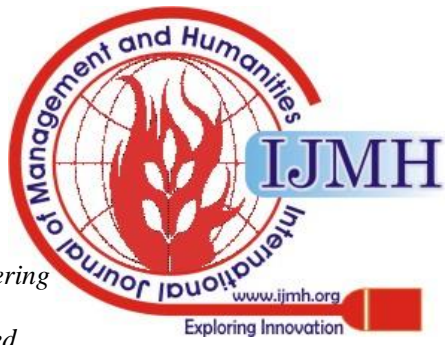


Assessment of the implementation of transport services has been investigated by a number of economists. They conducted independent research and development to determine the effectiveness of the provision of transport services and obtained specific results. However, due to the lack of comprehensive inclusive studies, our results of evaluating the services provided by the main types of transport enterprises were systematized in the following order (tab.5).

Table-V. The system of indicators for assessing the effectiveness of transport services ${ }^{7}$

\begin{tabular}{|c|c|}
\hline Group of indicators & The degree of assessment of indicators \\
\hline \multirow{5}{*}{$\begin{array}{l}\text { Quantitative indicators } \\
\text { in transport services }\end{array}$} & $\begin{array}{l}\text { The number of transport services to } \\
\text { perform one unit of work: kms., tons, } \\
\text { thousand people }\end{array}$ \\
\hline & $\begin{array}{l}\text { The volume of transport services } \\
\text { performed in one day: count. routes, tons, } \\
\text { kms, thousand people }\end{array}$ \\
\hline & $\begin{array}{l}\text { The volume of cargo transportation } \\
\text { services: tons, kms. }\end{array}$ \\
\hline & $\begin{array}{l}\text { Number of passenger traffic in transport: } \\
\text { billion passenger per km }\end{array}$ \\
\hline & Transport service scale: route (radius) \\
\hline \multirow{5}{*}{$\begin{array}{l}\text { Cost indicators in } \\
\text { transport services }\end{array}$} & $\begin{array}{l}\text { Added value from the creation of a unit of } \\
\text { services due to transport services: soums }\end{array}$ \\
\hline & $\begin{array}{l}\text { Gross (net) income from the provision of } \\
\text { transport services: soums }\end{array}$ \\
\hline & $\begin{array}{l}\text { Gross (net) profit from the provision of } \\
\text { transport services: soums }\end{array}$ \\
\hline & $\begin{array}{l}\text { The cost of the degree of attraction of } \\
\text { investments in the activities of transport } \\
\text { services: soums }\end{array}$ \\
\hline & $\begin{array}{l}\text { The cost of transport services from the } \\
\text { completed unit of resources (transport } \\
\text { equipment, labor, etc.): soums. }\end{array}$ \\
\hline \multirow{8}{*}{$\begin{array}{l}\text { Relative indicators in } \\
\text { transport services }\end{array}$} & $\begin{array}{l}\text { The degree of quality of transport } \\
\text { services:\% }\end{array}$ \\
\hline & $\begin{array}{l}\text { The degree of implementation of transport } \\
\text { services in a certain period:\% }\end{array}$ \\
\hline & $\begin{array}{l}\text { The degree of guarantee of the provision of } \\
\text { transport services:\% }\end{array}$ \\
\hline & $\begin{array}{l}\text { The degree of use (non-traditional } \\
\text { methods) of advanced technology in } \\
\text { transport services:\% }\end{array}$ \\
\hline & $\begin{array}{l}\text { he degree of compliance of the transport } \\
\text { service system with certain standards and } \\
\text { requirements:\% }\end{array}$ \\
\hline & $\begin{array}{l}\text { The degree of preservation of the } \\
\text { ecological balance of transport services: } \\
\text { point,\% }\end{array}$ \\
\hline & $\begin{array}{l}\text { Qualification of personnel of transport } \\
\text { services: point }\end{array}$ \\
\hline & Profitability of transport services:\% \\
\hline
\end{tabular}

In our opinion, the assessment of the effectiveness of transport services should be assessed taking into account the degree of customer satisfaction with the transport services provided by the transport service providers. The results of the assessment should be closely related to how cost-effective

${ }^{7}$ Designed from the author's scientific research the results of work and services performed by transport companies are. The effectiveness of enterprises providing transport services should be evaluated in quantitative, cost and relative terms. It is advisable to indicate the quantitative indicators of the provision of transport services in the form of the saved volume (cost) of the services rendered and the resources expended. Indicators of the cost of transport services, reflecting the cost of work and services, expressed in terms of money, give comparative estimates of their relative indicators (table 2 ). Thus, we can conclude that the practical results of the study are as follows:

Considering the peculiar feature of the sphere of transport services, the author formulates the definition of the transport services market in the work; the priority of participation of the Ministry of Economy of the Republic of Uzbekistan and its territorial divisions on the ground, the Ministry of Transport of the Republic of Uzbekistan and its structural divisions in organizational and economic relations in the cluster method, participating in the economic activities of the transport service sector is justified; recommendations are given to increase the number of consumers of transport infrastructure, to establish special benefits or preferential tariffs for sections of the population in need of social assistance; sources of coverage of these costs are identified. Studies show that in the Republic of Uzbekistan, in conditions of modernization and diversification of the economy to evaluate and improve the efficiency of transport services, the following economic indicators should be improved:

1. Improving the quantitative and qualitative indicators of road transport, in particular, it is important to increase such indicators as the frequency of the provision of road transport services, improve the quality of services provided to passenger fat, make services available to the population based on an increase in the volume of services and a decrease in their cost.

2. The use of performance indicators of the logistics system of automobile transport.

3. Lower transport costs, it should be noted that "... studies show that in developing countries the cost of transportation is 1.5 times higher than in developed countries. Depending on the condition of the roads, the speed of transportation may decrease by 1.5-1.6 times, operating costs of cars - by 1.6-2 times. Inconsistency of the state of automobile roads for vehicles ultimately leads to an increase in state budget expenditures.

4. Improvement of forecast indicators in a long-term strategy and the definition of elements of roadmaps for their implementation.

5. Indicators of the involvement of foreign and domestic investment in the development of transport services in the country.

In general, we can conclude that the formation of a scientifically based system of economic indicators will create conditions for increasing the efficiency of transport services and can monitor the targeted and targeted use of resources.

Published By:

Blue Eyes Intelligence Engineering \& Sciences Publication

(C) Copyright: All rights reserved.

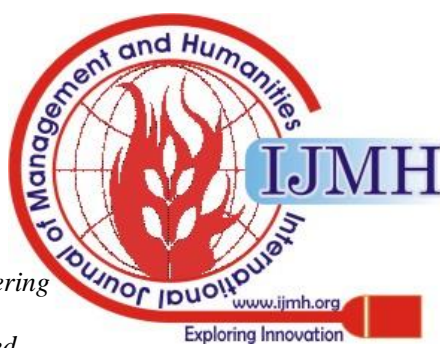




\section{CONCLUSIONS}

In the course of a scientific study of the development and increase of the efficiency of transport services, the following scientific and theoretical conclusions and methodological recommendations were developed:

1. Transport service is one of the most important sectors of the provision of public services, which in its structure and specifics of the material and technical base is significantly different from other sectors. According to the author's interpretation, transport services are a range of services related to services, such as transportation and delivery of passengers, loading, transportation, delivery, unloading and placement of goods using vehicles for profit.

2. Indicators for evaluating the effectiveness of transport services are distinguished by a peculiar approach, which, unlike indicators of efficiency in other areas, should be evaluated taking into account the degree of satisfaction with transport services provided by transport service providers. The results of the analysis indicate the impact of transport services on overall economic efficiency.

3. Organizational and economic mechanisms that ensure the efficient operation of the transport service process are scientifically substantiated. The paper also presents scientific proposals for improving the susceptibility of elements of economic, regulatory and organizational mechanisms based on their raising to a qualitatively new level.

4. According to the results of the scientific forecast, by 2021 the passenger flow is estimated at 186.5 billion passenger-km, the total number of passengers carried by this mode of transport will be 8565.6 million people and the total volume of transport services will amount to 68157 billion soums, these indicators will increase compared to the 2017 base year, respectively by $43.5 \%, 50.8 \%$ and $88.2 \%$.

\section{REFERENCES}

1. Bichkov V.P.(2004) Entrepreneurship in automobile transport. Piter

2. Burmenko T.D., Danilenko N.N., Turenko T.A.(2007) Sphere of services: economics. Knorus.

3. Dubrovskiy D.A.(2010) Profitable auto-service. Recommendations for managers. Piter.

4. Khamidov O.Kh.(2006) Organization of transport services. Tashkent - TSEU, page 4

5. Kadirov T.(2007) Approaches to Assessment of the Role of Road Transport in Ensuring Competitiveness of the Economy // Journal of Market, Money and Credit, 2013, p.4.

6. Nasimov I.Kh.(2018)Uzbekistan's economic foundations of the future strategy for the development of transport services // Journal of Management Value \& Ethics, Vol. 8 No. 3, pp. 50-61.

7. Nasimov I.Kh., Mirzaev Q.J. (2015) Transport cluster and its essential features // Conference on "Regional innovation systems in Agriculture," Kangwon National University, Samarkand Agricultural Institute, Samarkand.

8. Nemolyayeva M.E.(1985) International tourism: yesterday, today and tomorrow.

9. Ribalkin B.E.(2012) International Economic Relations. Uniti

10. Savitskaya G.E. (2000) Analogue to the business of company.

11. Vahrushina M.A., Karpova T.P., Petrov A.M.(2011) Accounting in sphere of services. Rid Group.

\section{AUTHORS PROFILE}

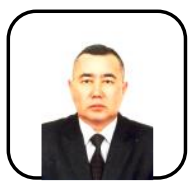

Prof. Mirzaev Kulmamat Janzakovich, was born in 1961. He did bachelor degree in agricultural economics in Tashkent Institute of National Economy. In 1982 he started to work as a junior researcher at the All-Union Karakul Research Institute of Samarkand. In 1989 he completed his postgraduate studies at the All-Union Agricultural Research Institute in Moscow and was employed in the
All-Union Karakul Research Institute of Samarkand, and later in Agricultural Economics and Management of the Samarkand Agricultural Institute. In 1996 he started to work as associate professor in the Samarkand Agricultural Institute. In 1998 he was promoted to the head of the department of Agricultural Economics and Management of the Samarkand Agricultural Institute. Between 2004 and 2005 he practiced in Training and Retraining Centre of Samarkand Agricultural Institute. After that he worked in the Treasury department of the Samarkand region and in Samarkand Institute of Economics and Service. Since 2015 he is working as a vice-rector on educational issues in the institute.

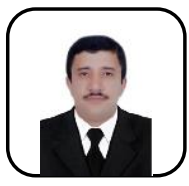

Ph.D. Nasimov Ikrom, was born in 1982. In 2004 he has started to work as a teacher in the $2^{\text {nd }}$ academic lyceum under Samarkand State University. In 2011 he finished his graduate studies in Samarkand Institute of Economics and Service. In 2012 he was hired in that institute as a deputy dean of the faculty of Economics, in 2013 as a teaching assistant and later in 2014 he was promoted to senior lecturer in the Department of Management and Statistics. At the moment he is working as a head of the department of Economic theory in Samarkand Institute of Economics and Service. He has published 19 works, from which three are in international journals: Uzbekistan's economic foundations of the future strategy for the development of transport services // Journal of Management Value \& Ethics, Vol. 8 No. 3, India, 2018. p.50-61, A system of indicators reflecting the effectiveness of transport services // "Economics and Entrepreneurship", M :. - 2016. - No. 10. (Part 1) - p. 522-525 and Important features of the transport services cluster // Proceedings of the International Conference on Economic and Environmental Problems of Small Business and Private Entrepreneurship Development in the Aral Sea Zone, - Nukus, 2015. - pp. 45-49.

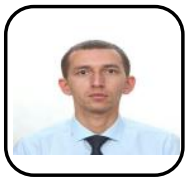

Rahimov Zafar, was born in 1990. In 2004 he finished his bachelor degree in economics at the Samarkand Agricultural Institute and enrolled in the master course in Economics of Samarkand Cooperative Institute. From 2017 up to date he has been working as a teacher in the Department of Industrial Economics of the Samarkand Institute of Economics and Service. Currently he is doing the research on Improving organizational and economic mechanisms in the development of service infrastructures in rural areas (in the region of Samarkand). He has published 20 articles. The following are his international publications: Ways to improve the quality of trade services in the context of innovative development of the economy (Scientific Electronic Journal "Economics and Innovative Technologies", January 1-February, 2019); Supporting the abundance of population by the development of service //Proceedings of the XI International Conference on "Institutional Development of Socio-Economic and Financial Systems: National Economy on a Global Level", May 16, 2019. 16-17 pp. 325-327; The use of the cluster approach to agro service development in Uzbekistan //Samarkand Institute of Economics and Service and Tambov State University Problems of Service Development in an Innovative and Digital Economy, Proceedings of the International Scientific Conference, pp. 49-52, 2020.
Published By: Blue Eyes Intelligence Engineering \& Sciences Publication (C) Copyright: All rights reserved.

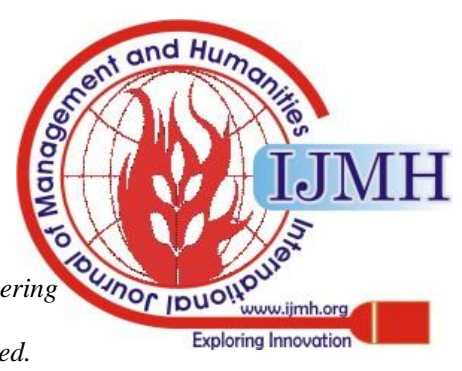

